\title{
Review: Hunter Vaughan, Hollywood's Dirtiest Secret: The Hidden Environmental Costs of the Movies
}

Cassice Last

https://doi.org/10.15664/fcj.v0i17.2056

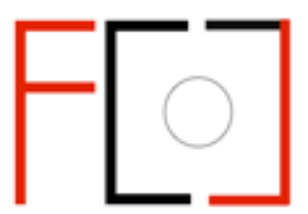

Frames Cinema Journal

ISSN 2053-8812

Issue 17 (Jun 2020)

http://www.framescinemajournal.com

(c) (i) 


\section{Hollywood's Dirtiest Secret: The Hidden Environmental Costs of the Movies By Hunter Vaughan \\ Columbia University Press, 2019 \\ Reviewed by Cassice Last, University of St Andrews}

In Hollywood's Dirtiest Secret: The Hidden Environmental Costs of the Movies (2019), Hunter Vaughan takes a vibrant and interdisciplinary look into the environmental impact of producing, advertising, watching, distributing, and buying films. Focusing predominantly on Hollywood, his investigation encompasses films such as Twister (Jan de Bont, 1996), Singin' in the Rain (Gene Kelly and Stanley Donan, 1952), The Life of an American Fireman (Edwin S. Porter, 1903), and Avatar (James Cameron, 2009). Despite spending some time on textual analysis, and indeed he defends the validity of this method for examining Hollywood's relation to the environment, his investigation goes beyond this through archival research, historical analyses, genre studies, and a foray into a relational-values approach. To justify his approach, he argues that the environmental discussion would benefit from a stronger communication between media studies, social sciences, and the humanities.

Vaughan's overall goal is to "attempt an accessible environmentalist study of popular films across Hollywood history", considering "how films have both shaped and reflected - and continue to shape and reflect - our relationship with the nonhuman world" (5). Throughout his investigation, he keenly reiterates the need to recognise or re-acknowledge the material impact films have on the world. While he is insistent that his study is not intended to lay blame on any individual or their actions, his work is organised around the belief that the best way forward in lessening the environmental costs of films is to lay bare their damaging material impacts. To this end, he highlights the need to address a core value of Hollywood, one in which viewers are complicit: "the sacrifice of the real on the altar of entertainment spectacle" (2). He proposes, firstly, acknowledging that this "sacrifice" has a material impact and, secondly, analysing in detail the full weight of these consequences. His work is organised into five chapters. The first three chapters take a closer look at Hollywood's specific manipulation of the environment, focusing on fire, water, and wind respectively, while the final two examine a digitised Hollywood and the concept of positioning Hollywood as an invasive species. Throughout his investigation, he underscores the absolute necessity that viewers and filmmakers alike "begin to fully assess the complex relationships among our screens, our natural resources, and the ecosystems, ecologies, and economies they are a part of' and make visible the obscured material costs of films (7).

Chapter One investigates Hollywood's use of fire, with an emphasis on the material impact of burning down buildings for films. Vaughan closely examines Gone with the Wind (Victor Fleming, 1939). He translates the human desire to see objects burn into a kind of agreement wherein we seek "to convert reality into destruction spectacle" (26). While highlighting several explosively destructive recent blockbusters, such as Godrilla (Gareth Edwards, 2014) and Furious 7 (James Wan, 2015), he also points to a fiery history of American films, including Thomas Edison's Starting for the Fire (1896) and Fighting the Fire (1896). He links the onscreen explosive spectacle to the volatile chemical nature of film itself and then, later, to a kind of "collective catharsis" (36). He ends this chapter with a thorough analysis of the burning of Atlanta sequence from Gone with the Wind, employing eye-witness testimony and archived memos.

Chapter Two takes Singin' in the Rain as the main point of inquiry for an examination of Hollywood's use of water. Vaughan underscores how vital water is to the general population, before then outlining the many ways in which water is necessary to the filmmaking, distribution, 
and watching process. He further highlights the power of water on screen through the ways it has been used to raise awareness about global warming, and he cites The Day After Tomorrow (Roland Emmerich, 2004) for its plot, scenes of spectacle, and its promotion as a "carbon-neutral production". Vaughan highlights however that, whether carbon-neutral or not, the film process requires an immense amount of water usage and wastage, and to this end, he discusses the extreme example provided by James Cameron's Titanic (1997). He closes the chapter by analysing Singin' in the Rain and its general theme of being complicit with artifice, before positioning this as an environmental issue wherein "we position the nonhuman natural world as expendable fuel for our popular entertainment" (78).

Chapter Three examines The Wind (Victor Sjöström, 1928) and Twister, initially to consider how wind functions in cinema and then, more broadly, to reflect on how Hollywood films make visible the invisible matters of the environment. Continuing the discussion begun in Chapter Two regarding Hollywood's contract with artifice, he highlights the Hollywood myth of its own "wizardry", arguing that what the industry has "perfected is the presentation of itself as a magically conjured realm of virtual worlds, not as a product of matter" (93). He foregrounds a link between the Scientist-Hero archetype emerging in eco-disaster films and the offscreen technician "intertwining production discourse and representational meaning [...] in which the diegetic scientist acts as a stand-in for the directorial wizard behind the filmmaking curtain" (93). With this in mind, he examines how films have used special effects to visualise the invisible effects of climate change and selects the wind as his subject. After a brief glance at The Wind, he ends his chapter with a thorough analysis of Twister.

Chapter Four examines "film culture's transition to the digital age" and takes a closer look into the emergence of "digital Hollywood", situating our current era within this technological moment $(126,169)$. Once more, Vaughan emphasises that new film technologies have continued to shroud the material impact that films have on the environment. He investigates genre here, positioning the eco-disaster film within the broader science fiction genre to uncover its relationship to the apocalypse and placing a particular emphasis on the theme of responsibility. After establishing the importance of responsibility in this context, he unpicks the myth that digital technology is "some miraculously green network" (137). He then highlights "the great irony of the eco-disaster genre": as a form of green-washing for films at "the forefront of a neoliberal digital turn" (140). To this end, he closes his chapter by analysing Avatar and its extreme use of CGI to create a new on-screen reality and environment.

Finally, in Chapter Five, Vaughan characterises Hollywood productions as a kind of "invasive species" that affect a locale's environment, economy, and human health (165). Vaughan outlines how Hollywood often functions as a series of decentralised productions that quickly colonise an area for the duration of shooting, before abandoning the site. He investigates two case studies, Michigan (2008-2016) and Florida (2010-2016), in the hope that his work will "encourage more dynamic ways of understanding how such programs interact with human groups and the natural environment" (190).

Vaughan leaves the reader with a sense of hope in his conclusion. Throughout his work, he reveals how films have had an extremely damaging environmental impact, but he is keen to point out that changes can and have been made. Situating his book as a plea "for us to consider the environmental ramifications and role of screen culture", he urges readers to see themselves as part of this world, able to enact meaningful change (194). 